\title{
The Protective Effects of N-Acetyl-L-cysteine on Cadmium-induced Cell Apoptosis in Rat Testis
}

\author{
$\mathrm{Ji}^{-S u n} \mathrm{Kim}^{1 *}$ and Jaemog $\operatorname{Soh}^{2, ; ; * *}$ \\ ${ }^{1}$ Medical University of South Carolina, Charleston, SC 29425,USA \\ ${ }^{2}$ Hormone Research Center, Division of Biological Sciences and Technology, \\ College of Natural Sciences, Chonnam National University, Gwangju 61186, Korea
}

\begin{abstract}
Cadmium (Cd) generates reactive oxygen species (ROS), which in turn cause the apoptosis of various cell types including developing germ cells in rodent testis. Ascorbic acids (AA), one of the ROS scavengers, had been reported to protect against Cd-induced apoptosis. N-Acetyl-L-cysteine (NAC), another ROS scavenger, is known to remove ROS and alleviate the $\mathrm{Cd}$-induced apoptosis in various cell types. In this study we tried to elucidate how NAC affected on $\mathrm{Cd}$-induced cell apoptosis in rat testis. Rats were administered with NAC before and after Cd treatment and then testicular cell apoptosis was examined. NAC treatment resulted in the reduction of Cd-induced chromosomal DNA fragmentation in agarose gel electrophoresis. Terminal deoxynucleotidyl transferase dUTP nick end-labeling (TUNEL) assay showed that treatment of NAC reduced the Cd-induced apoptosis of germ cells. The administration of NAC showed that the translocation of apoptosis inducing factor (AIF) from mitochondria to nucleus was prevented, which indicated that the mechanism of Cd-induced testicular apoptosis is mediated through the release of AIF in caspase-independent manner. Taken together, the NAC may remove Cd-induced ROS and protect ROS-induced cell apoptosis in rat testis.
\end{abstract}

Key Words: N-Acetyl-L-cysteine, Cadmium, Apoptosis, Testis, Rat

\section{INTRODUCTION}

Cadmium $(\mathrm{Cd})$ is a reproductive toxicant in rodents as well as humans. Previous studies demonstrated that there is a significant inverse correlation between blood $\mathrm{Cd}$ level and sperm quality (Pant et al., 2015; Li et al., 2016). It was shown that even a low level of Cd accumulation in semen contributed to male infertility by reducing sperm quality in rats (Zhao et al., 2015). Rodent studies have revealed that $\mathrm{Cd}$ had induced germ cell apoptosis in the testis (Xu et al.,
1996; Sen Gupta et al., 2004).

The toxic effects of $\mathrm{Cd}$ seem to be indirect and are at least in part due to oxidative stress induced by exposure to Cd (Lopez et al., 2006). Cd is known to induce reactive oxygen species (ROS) (Khojastehfar et al., 2015). Excessive Cd-induced ROS in turn plays an important role in the induction of apoptosis. ROS causes mitochondria to release Cytochrome c, which triggers caspase activation (Simon et al., 2000). Treatment of caspase inhibitors was reported to block Cd-induced apoptosis in certain cells ( $\mathrm{Li}$ et al., 2000). In contrast, the caspase-independent pathway, which is involved

Received: September 16, 2019 / Revised: November 27, 2019 / Accepted: November 27, 2019

* Graduate student, ${ }^{* *}$ Professor.

${ }^{\dagger}$ Corresponding author: Jaemog Soh. Hormone Research Center, Division of Biological Sciences and Technology, College of Natural Sciences, Chonnam National University, Buk-gu, Yongbong-ro 77, Gwangju 61186, Korea.

Tel: +82-62-530-1035, Fax: +82-62-530-2199, e-mail: jaemsoh@gmail.com

(C) The Korean Society for Biomedical Laboratory Sciences. All rights reserved.

(c) This is an Open Access article distributed under the terms of the Creative Commons Attribution Non-Commercial License (http://creativecommons.org/licenses/by-nc/3.0/) which permits unrestricted non-commercial use, distribution, and reproduction in any medium, provided the original work is properly cited. 
the translocation of apoptosis-inducing factor (AIF) from mitochondria to the nucleus, was reported to be associated with Cd-induced apoptosis in liver Hep3B cells (Lemarie et al., 2004). AIF is responsible for chromatin condensation, DNA fragmentation and the formation of apoptotic bodies (Krantic et al., 2007). It is reported that endoplasmic reticulum stress signaling with mitochondria is involved in Cd-induced germ cell apoptosis (Ji et al., 2011). However, the molecular mechanism of Cd-mediated testicular germ cell apoptosis has not been elucidated clearly yet.

The effect of ROS reactive oxygen is ameliorated by the antioxidant action of non-enzymatic antioxidants such as vitamin C and E (Sen Gupta et al., 2004; Acharya et al., 2008). It has been reported that selenium, and melatonin showed a protective effect on germ cell death by $\mathrm{Cd}$-induced oxidative stress in rodents (Ognjanovic et al., 2008; Li et al., 2016).

$\mathrm{N}$-Acetyl-L-cysteine (NAC) is considered an antioxidant because it acts as a reduced glutathione (Aldini et al., 2018). It plays a central role in protecting cells from oxidative stress and oxygen-derived injury in renal tissue (Kaplan et al., 2008). It has been reported that NAC showed efficient antioxidant activity in vitro (Sagrista et al., 2002; Ates et al., 2008) as well as in vivo (Dhanda et al., 2013, Ortiz et al., 2016). However, the mechanism by which NAC protects against $\mathrm{Cd}$-induced germ cell apoptosis is not clearly understood yet. The purpose of our study was to get an insight into the mechanism by which NAC protects against $\mathrm{Cd}$-induced apoptosis in rat testicular cells.

\section{MATERIALS AND METHODS}

\section{Chemicals and animals}

Cadmium chloride and $\mathrm{N}_{\text {-acetyl }}{ }_{-}$-cysteine (NAC) was purchased from Sigma (MO, U.S.A.). Adults male Sprague Dawley rats weighting 230 250 g were obtained from Daehan Biolink Co. (South Korea). Animals were allowed to acclimatize for 1 week before experiments. Animals were housed in a standard animal facility under the controlled temperature $\left(22^{\circ} \mathrm{C}\right)$, and light schedule was maintained at $12 \mathrm{~h}$ of light per day with free access to water and rat pellets. All treatments and procedures were in accordance with the protocol of Chonnam National University Committee's Guidelines for the care and use of experimental animals.

\section{Cadmium and NAC treatment}

Each experimental group consists of four rats. Experimental groups were treated with different doses $(0.1 \sim 0.3 \mathrm{mg}$ $/ 100 \mathrm{~g}$ body weight, BW) of cadmium chloride (anhydrous) by subcutaneous (s.c.) injection at $24 \mathrm{~h}$ prior to sacrifice. In NAC supplementation groups, $150 \mathrm{mg} / 100 \mathrm{~g} \mathrm{BW}$ of NAC was pretreated (s.c.) for $24 \mathrm{~h}$ prior to $\mathrm{Cd}$ administration, followed by an additional injection of NAC $(50 \mathrm{mg} / 100 \mathrm{~g}$ $\mathrm{BW}$ ) three times at an interval of $8 \mathrm{~h}$ before sacrifice (at $24 \mathrm{~h}$, $18 \mathrm{~h}$, and $8 \mathrm{~h}$ prior to sacrifice). In NAC-only group, $150 \mathrm{mg}$ $/ 100 \mathrm{~g} \mathrm{BW}$ of NAC was pretreated $48 \mathrm{~h}$ before sacrifice, and $50 \mathrm{mg} / 100 \mathrm{~g} \mathrm{BW}$ of additional NAC injection was followed at an interval of $8 \mathrm{~h}$ before sacrifice three times. Control groups were administered with only normal saline instead of Cd for $24 \mathrm{~h}$ and instead of NAC for $48 \mathrm{~h}$.

\section{DNA gel electrophoresis}

DNA fragmentation was determined by the observation of DNA laddering. DNA was isolated from testis using DNeasy tissue DNA purification kit (Qiagen, CA, U.S.A.) (Siu et al., 2004). Briefly, testis tissue were lysed with a lysis buffer containing proteinase $\mathrm{K}$ for overnight at $55^{\circ} \mathrm{C}$. The lysed samples were then treated with RNase $(50 \mu \mathrm{g} / \mathrm{mL})$ for $1 \mathrm{~h}$ at $37^{\circ} \mathrm{C}$. DNA was extracted and then eluted using the silica-gel-membrane column provided with the kit. Ten micrograms $(\mu \mathrm{g})$ of isolated DNA was electrophoresed on $1.5 \%$ agarose gel and visualized by staining with $1 \mu \mathrm{g} / \mathrm{mL}$ ethidium bromide (EtBr) in Tris/ borate/ EDTA (TBE) buffer. Gels were photographed under ultraviolet transilluminator.

\section{TUNEL assays}

To observe DNA strand breaks in nuclei at the cellular level, the terminal deoxynucleotidyl transferase-mediated dUTP nick end-labeling (TUNEL) assay was performed using the TUNEL Assay System (DeadEnd ${ }^{\mathrm{TM}}$ Colorimetric TUNEL system, Promega, WI, U.S.A.) as described (Sen Gupta er al., 2004). Briefly, testes were fixed with $4 \%$ paraformaldehyde, dehydrated, and embedded in paraffin, before being cut into 5 - $\mu \mathrm{m}$-thick sections. The sections were 
mounted on slides coated with gelatin-subbing solution and were then deparaffinized and hydrated. The samples were washed with immersing solution (potassium buffered saline, PBS) at room temperature. The tissue sections were fixed with $4 \%$ paraformaldehyde solution at room temperature and then washed with PBS twice. Each slide was treated with $20 \mu \mathrm{g} / \mathrm{mL}$ proteinase $\mathrm{K}$ solution, followed by washing with PBS twice. After re-fixation with $4 \%$ paraformaldehyde, the tissues were covered with cell equilibration buffer $(200 \mathrm{mM}$ potassium cacodylate, $25 \mathrm{mM}$ Tris- $\mathrm{HCl}, \mathrm{pH} 6.6,0.2 \mathrm{mM}$ DTT, $0.25 \mathrm{mg} / \mathrm{mL}$ BSA, $2.5 \mathrm{mM}$ cobalt chloride) and treated with $100 \mu \mathrm{L}$ reaction mix (biotinylated nucleotide mix and recombinant terminal deoxynucleotidyl transferase (rTdT) in equilibration buffer). The sections were covered with plastic cover slips to ensure the even distribution of the reagent, and were incubated at $37^{\circ} \mathrm{C}$ for $60 \mathrm{~min}$. To remove the unincorporated biotinylated nucleotides, the slides were incubated again in $2 \times \mathrm{SSC}$ at room temperature and washed with fresh PBS twice. Endogenous peroxidase was blocked by immersing the slides in $0.3 \%$ hydrogen peroxide at room temperature. After washes four times with PBS, horseradish peroxidase-labeled streptavidin (HRP-streptavidin) diluted in PBS was added to slides for $30 \mathrm{~min}$ at room temperature. 3, 3-diaminobenzidine (DAB) was used for the coloration of apoptotic cells. DNase I-treated tissue was used as a positive control. The reaction without rTdT enzyme was used as a negative control. For statistical analysis, germ cells were counted in fields selected by the systematic random approach and the number of TUNEL-positive cells was counted per 1,000 germ cells.

\section{Preparation of nuclear and mitochondrial fractions}

Mitochondrial and nuclear fractions of testes were pre pared as described previously (Cox and Emili, 2006). Briefly, $50 \mathrm{mg}$ of testes were washed with ice-cold $250 \mathrm{mM}$ STMDPS buffer (50 mM Tris-HCl, pH 7.4, $250 \mathrm{mM}$ sucrose, $5 \mathrm{mM} \mathrm{MgCl} 2,1 \mathrm{mM}$ DTT, $1 \mathrm{mM}$ PMSF, $25 \mu \mathrm{g} / \mathrm{mL}$ spermine, and $25 \mu \mathrm{g} / \mathrm{mL}$ spermidine) and then submerged in 250STMDPS buffer. After 15 strokes in a Dounce homogenizer, the extract was centrifuged at $800 \mathrm{~g}$ for $15 \mathrm{~min}$, and the pellet (pellet-I) was used to prepare the nuclear fraction. The above supernatant was centrifuged again at $6,000 \mathrm{~g}$ for
15 min. The pellet was further sonicated and used for the mitochondrial fraction. The above pellet (pellet-I) was homogenized with a single stroke in a Dounce homogenizer in 2 M-TMDPS buffer (50 mM Tris-HCl, pH 7.4, 2 M sucrose, $5 \mathrm{mM} \mathrm{MgCl}_{2}, 1 \mathrm{mM}$ DTT, $1 \mathrm{mM}$ PMSF, $25 \mu \mathrm{g} / \mathrm{mL}$ spermine, and $25 \mu \mathrm{g} / \mathrm{mL}$ spermidine) and fractionated at 8,000 $\mathrm{g}$ for $35 \mathrm{~min}$. The resulting pellet (pellet-II) was resuspended in nuclear extract buffer (20 mM HEPES, pH 7.9, $1.5 \mathrm{mM}$ $\mathrm{MgCl}_{2}, 0.5 \mathrm{M} \mathrm{NaCl}, 0.2 \mathrm{mM}$ EDTA and 20\%, glycerol) and used as the nuclear fraction. Total testicular protein was prepared as described previously (Jahnukainen et al., 2004).

\section{Western blot analysis}

Equivalent amount $(60 \mu \mathrm{g})$ of protein extracts, as determined by the Bradford Method (Bio-Rad Italy, Segrate, Italy), were resolved by SDS-PAGE and processed for Western blot analysis (Gomes et al., 2005). Nonspecific binding sites were blocked by incubating the membranes in 5\% non-fat milk in Tris-buffered saline (TBS) with $0.1 \%$ Tween 20 (TBS-T) for $1 \mathrm{~h}$ at room temperature. Membranes were incubated with primary antibodies in blocking solution for $12 \mathrm{~h}$ at $4^{\circ} \mathrm{C}$ and then washed three times with TBS-T for $10 \mathrm{~min}$. Membranes were incubated with anti-mouse or antirabbit antibodies conjugated with HRP for $3 \mathrm{~h}$ at room temperature and then washed three times with TBS-T for $10 \mathrm{~min}$. Immunoreactive proteins were visualized using an ECL Kit (Amersham Bioscience, U.K), according to the manufacturer's instructions. The antibodies used were rabbit anti-AIF (1:500; Chemicon Temecula CA, U.S.A.), mouse anti-COX IV (1:2,000; Abcam Cambridge, U.K), and mouse antiHistone (1:1,000; Santacruz, California, U.S.A.).

\section{Immunofluorescence assay}

Immunofluorescence assay was performed as described previously (Gomes and Soh, 2017). Testes were fixed with $4 \%$ paraformaldehyde, dehydrated, and embedded in paraffin, before being cut into 5 - $\mu \mathrm{m}$-thick sections. The sections were mounted on slides coated with gelatin-subbing solution and were then deparaffinized and hydrated. Samples were permeabilized four times by boiling in $10 \mathrm{mM}$ citrate buffer (pH 6.0) for $2 \mathrm{~min}$. After cooling, the samples were incubated in blocking buffer (2\% goat serum, $2 \%$ BSA in PBS) for 
30 min. Samples were then incubated with primary antibodies for overnight. The primary antibodies were rabbit anti-AIF (1:500; Chemicon, CA, U.S.A.) and mouse antiCOX IV (1:500; Abcam, U.K). After incubation with primary antibodies, samples were incubated with Alexa Fluor ${ }^{\circledR} 488$ anti-rabbit (Molecular probes, OR, U.S.A.) and Texas red anti-mouse antibodies (Santa Cruz, CA, U.S.A.) for $2 \mathrm{~h}$, and then the slides were photographed using a laser confocal microscope system (Leica, Germany).

\section{Statistics}

The intergroup differences were used to measure statistically significant differences among groups using Students's $t$-test. A difference was considered to be significant if $P<$ 0.05

\section{RESULTS}

\section{Protective effect of NAC on DNA fragmentation induced by Cd treatment}

To examine the effect of NAC on Cd-induced apoptosis, DNA fragmentation was tested on agarose gel with $\mathrm{Cd}$ exposed rat germ cells in the presence or absence of NAC. The typical formation of DNA fragmentation, which is shown as ladders on agarose gels, was observed in $0.1 \mathrm{mg}$ $/ 100 \mathrm{~g} \mathrm{BW}, 0.2 \mathrm{mg} / 100 \mathrm{~g} \mathrm{BW}$, and $0.3 \mathrm{mg} / 100 \mathrm{~g} \mathrm{BW}$ of Cdtreated rat testis, while little fragmentation was seen without Cd treatment (Fig. 1, lane 2: negative control and lane 6: NAC only). The results showed that the level of the fragmentation was enhanced in Cd-treated rats in dose-dependent manner (Fig. 1, lanes 3 to 5). In contrast, the addition of $\mathrm{NAC}$ in $0.1 / 100 \mathrm{~g} \mathrm{BW}, 0.2 / 100 \mathrm{~g} \mathrm{BW}$, and $0.3 \mathrm{mg} / 100 \mathrm{~g}$ BW Cd-treated groups reduced DNA fragmentation (Fig. 1, lanes 7 to 9) compared to the Cd-only treated groups, respectively. The results demonstrated that NAC might have an inhibitory effect on Cd-induced DNA fragmentation in rat germ cells.

\section{Protective effect of NAC on formation of DNA strand breaks induced by Cd treatment (TUNEL assay)}

To confirm the protective effect of NAC on Cd-induced apoptosis further, DNA strand breaks was measured using a
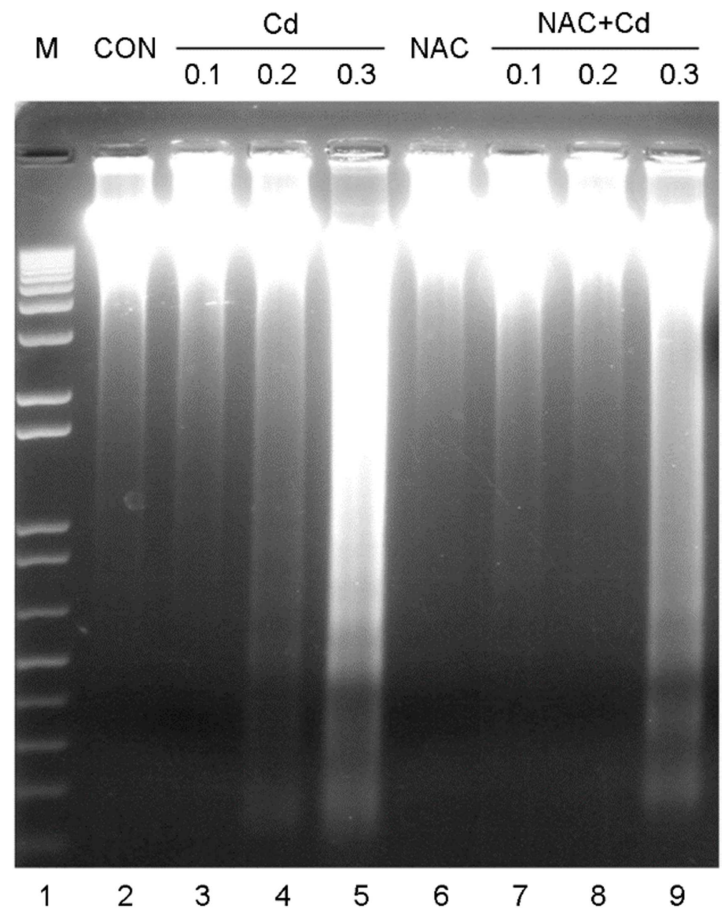

Fig. 1. Repressive effect of NAC on DNA fragmentation of Cdtreated rat testicular cells. The fragmentation of genomic DNA from rat testis tissues was visualized by staining with ethidium bromide. Each mouse was injected with different doses of $\mathrm{Cd}$ and/ or NAC by s.c. injection. Lane 1: 1kb DNA ladders; lane 2: control

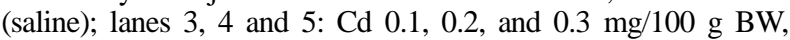
respectively. Lane 6: NAC only; lane 7: Cd $0.1 \mathrm{mg}+\mathrm{NAC}$; lane 8: Cd $0.2 \mathrm{mg}+$ NAC; lane 9: Cd $0.3 \mathrm{mg}+$ NAC. NAC was administered at $150 \mathrm{mg} / 100 \mathrm{~g} \mathrm{BW} 24 \mathrm{~h}$ prior to Cd treatment and further administered three times at $50 \mathrm{mg} / 100 \mathrm{~g} \mathrm{BW}$ at $24 \mathrm{~h}, 16 \mathrm{~h}$, and $8 \mathrm{~h}$ each prior to sacrifice. The experiment was repeated three times with similar results.

TUNEL assay. The number of apoptotic cells in the testes were increased by $\mathrm{Cd}$ treatment (Fig. 2 c, 2 e) compared with the control group (Fig. 2 a). Cell necrosis was observed with considerable cell shrinkage at the highest $\mathrm{Cd}$ dose (0.3 mg/100 g BW) (Fig. 2 g). On the other hand, the number of apoptotic cells substantially decreased with NAC supplementation in the Cd-treated group (Fig. $2 \mathrm{~d}, 2 \mathrm{f}$ ) compared with the Cd-only treated groups (Fig $2 \mathrm{c}, 2 \mathrm{e}$ ). The results indicated that supplementation with NAC might protect against the necrosis of testis germ cells induced by $\mathrm{Cd}$ treatment (Fig. 2 h) when compared with the Cd-only treated group (0.3 mg/100g BW) (Fig. 2 g). TUNEL-positive germ cells were counted as described in materials and methods. The number of TUNEL-positive cells counted per 1,000 

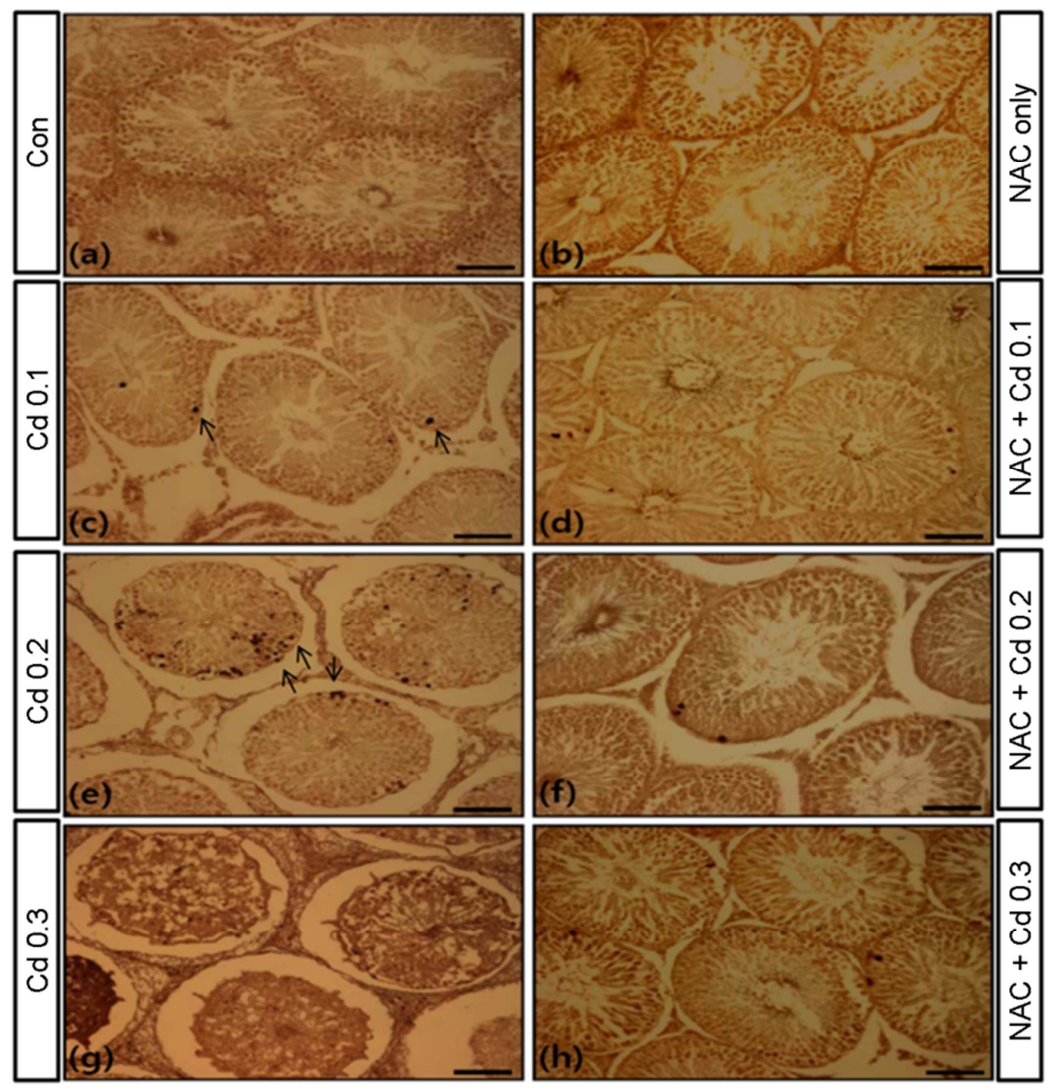

Fig. 2. Effect of NAC on Cd-induced apoptosis in rat testes by TUNEL assay. (a) Negative control (saline); (b) NAC only; (c) Cd $0.1 \mathrm{mg} / 100 \mathrm{~g} \mathrm{BW}$; (e) Cd $0.2 \mathrm{mg} / 100 \mathrm{~g}$ $\mathrm{BW}$; (g) Cd $0.3 \mathrm{mg} / 100 \mathrm{~g} \mathrm{BW}$; (d) Cd $0.1 \mathrm{mg}$ + NAC; (f) Cd $0.2 \mathrm{mg}+\mathrm{NAC}$; (h) Cd $0.3 \mathrm{mg}$ + NAC. Arrows indicate apoptotic cells. NAC was administered at $150 \mathrm{mg} / 100 \mathrm{~g} \mathrm{BW} 24 \mathrm{~h}$ prior to $\mathrm{Cd}$ treatment and further administered three times at $50 \mathrm{mg} / 100 \mathrm{~g} \mathrm{BW}$ at $24 \mathrm{~h}, 16 \mathrm{~h}$, and $8 \mathrm{~h}$ each prior to sacrifice. Representative photographs are shown here. The scale bar represents $20 \mu \mathrm{m}$.

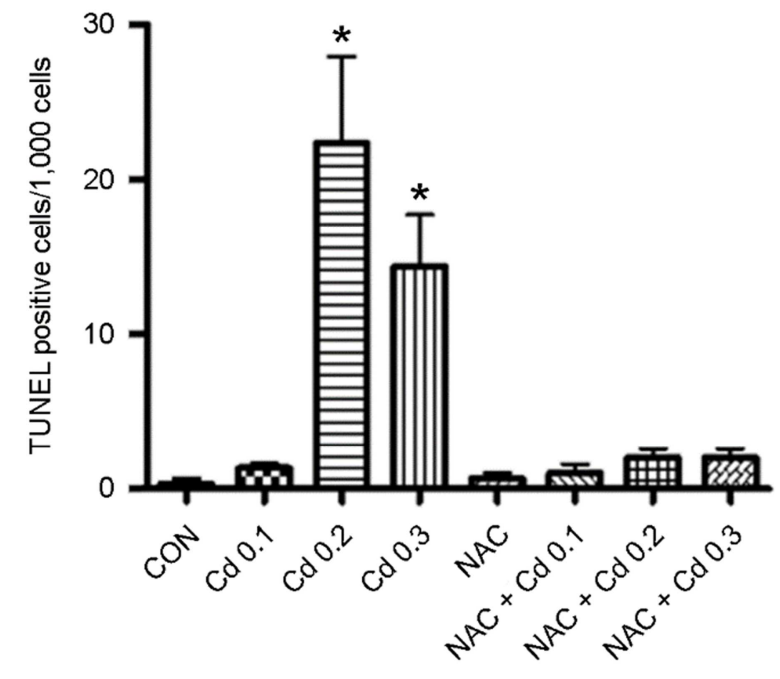

Fig. 3. Quantitative analysis of TUNEL positive cells in Cdtreated rats and NAC supplemented rat testes. Germ cells were counted in fields selected by a systematic random approach and the number of TUNEL-positive cells was counted per 1,000 germ cells as described in materials and methods (mean \pm S.E.M.). The experiment was repeated three times with similar results. An asterisk indicates a significant difference $(P<0.01)$ compared with the control. germ cells (mean \pm S.E.M.) are shown in Fig. 3. The results showed that there was a protective effect of NAC treatment on Cd-induced DNA breaks formation, which leads to the apoptosis and necrosis of developing germ cells in rats.

Inhibition of Cd-induced translocation of apoptosisinducing factor (AIF) from mitochondria to nucleus in NAC treated rat testis

It was reported that Cd-induced apoptosis in MRC-5 fibroblast cells and rat testis was mediated by the depolarization of the mitochondrial membrane and translocation of AIF from the mitochondria to the nucleus (Shih et al., 2004; Kim and Soh, 2009). To determine whether the protective activity of NAC on Cd-induced apoptosis is mediated by the inhibition of AIF translocation from mitochondria to nucleus fractionation, Western blot analysis was employed. As shown in Fig. 4, Cd treatment decreased the mitochondrial localization of AIF, while the nuclear localization of AIF was significantly increased. However, NAC supplementation 
(A)

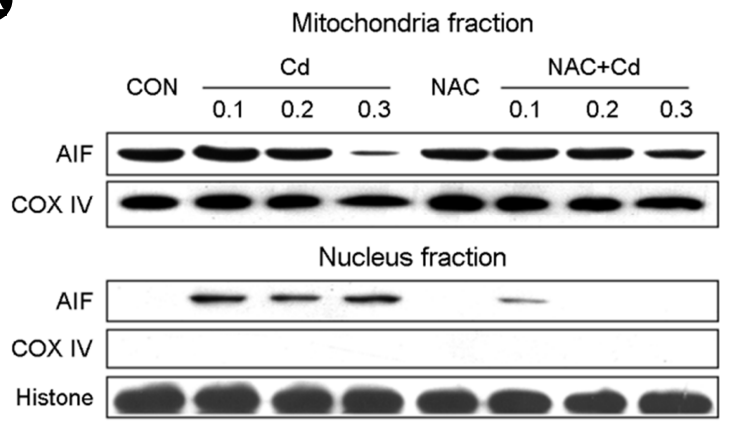

B
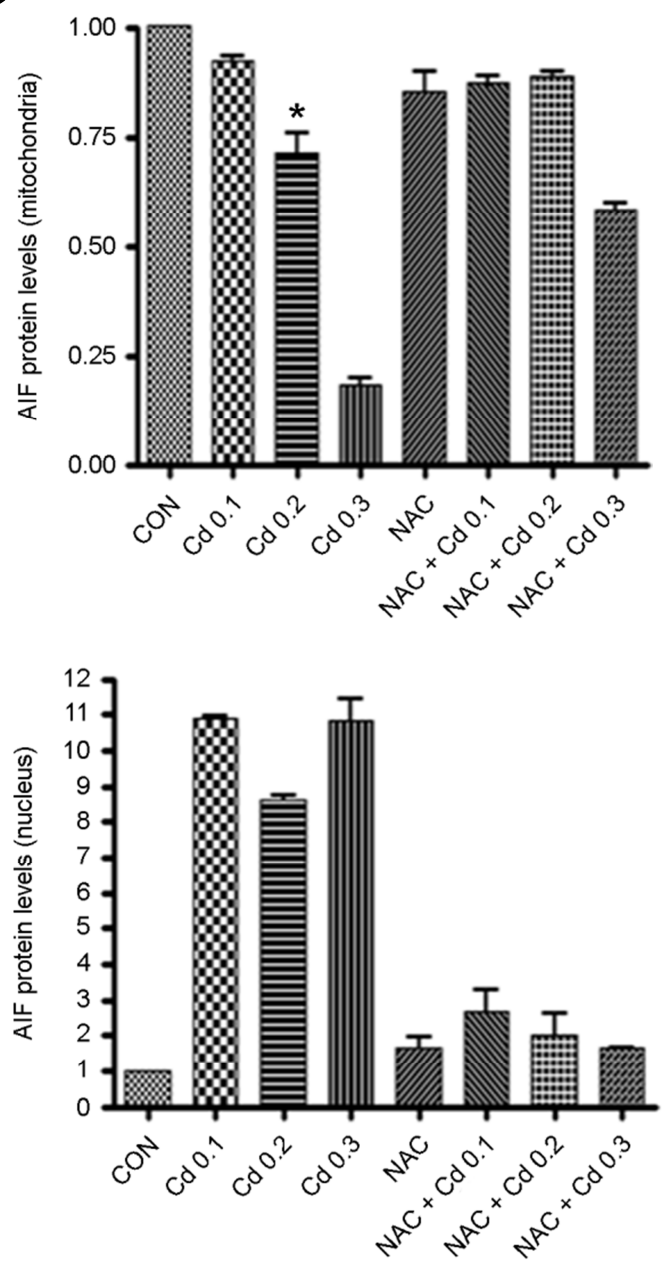

Fig. 4. Effect of NAC on Cd-induced translocation of apoptosisinducing factor (AIF) in rat testes. (A) Western blot analysis of AIF translocation with fractionated mitochondrial and nuclear protein from Cd-only $(0.1,0.2,0.3 \mathrm{mg} / 100 \mathrm{~g} \mathrm{BW})$ groups and NAC supplemented groups. NAC was administered at $150 \mathrm{mg} / 100 \mathrm{~g} \mathrm{BW}$ $24 \mathrm{~h}$ prior to $\mathrm{Cd}$ treatment and further administered three times at $50 \mathrm{mg} / 100 \mathrm{~g} \mathrm{BW}$ at $24 \mathrm{~h}, 16 \mathrm{~h}$, and $8 \mathrm{~h}$ each prior to sacrifice. Antibodies against COX IV and histone were used as mitochondrial and nuclear protein localization markers, respectively. The experiment was repeated three times with similar results. (B) Integrated optical density (IOD) values of the AIF protein levels. An asterisk indicates a significant difference $(P<0.05)$ compared with the control. repressed the translocation of AIF from the mitochondria to the nucleus in Cd-treated rat germ cells. Therefore, it can be concluded that NAC inhibits Cd-induced apoptosis in rat testis by alleviating the depolarization of the mitochondrial membrane.

To confirm the effects of NAC on Cd-induced AIF translocations further, immunofluorescence analysis was conducted to observe the cellular localization of AIF. The testis were fixed and labeled with antibodies against AIF (green fluorescence) and COX IV (red fluorescence), which is used as an indicator of mitochondria localization. While AIF protein was solely localized in the mitochondria in the control group (Fig. 5 a-1) and NAC-only treated group (Fig. $5 \mathrm{c}-1)$. In Cd-treated rats, AIF is released to the nucleus in (Fig. 5 b-1). However, NAC significantly inhibited Cdinduced AIF translocation from the mitochondria to the nucleus (Fig. 5 d-1). These results again demonstrated that NAC suppresses Cd-induced apoptosis with the inhibition of AIF translocation from the mitochondria to the nucleus in rat testis.

\section{DISCUSSION}

There had been inconsistent reports on detailed mechanism underlying Cd-induced apoptosis. Treatment of caspase inhibitors was shown to block Cd-induced apoptosis in certain cells (Kondoh et al., 2002). However the caspaseindependent pathway, which involves the translocation of AIF from mitochondria to the nucleus was associated with Cd-induced apoptosis in human lung fibroblasts (Lemarie et al., 2004). This discrepancy might be due to differences in the cell lines used or to variations in the experimental conditions.

We previously demonstrated that $\mathrm{Cd}$-induced apoptosis in rat testicular germ cells through the production of ROS and that apoptosis induced by increased ROS was prevented by the supplementation of ascorbic acid (AA), a ROS scavenger (Sen Gupta et al., 2004). We previously demonstrated that the administration of AA to Cd-treated rat inhibited the translocation of AIF from the mitochondria to the nucleus in rat testis, and the up-regulation of PARP-1 (poly ADPribose polymerase-1) (Kim and Soh, 2009). These results 


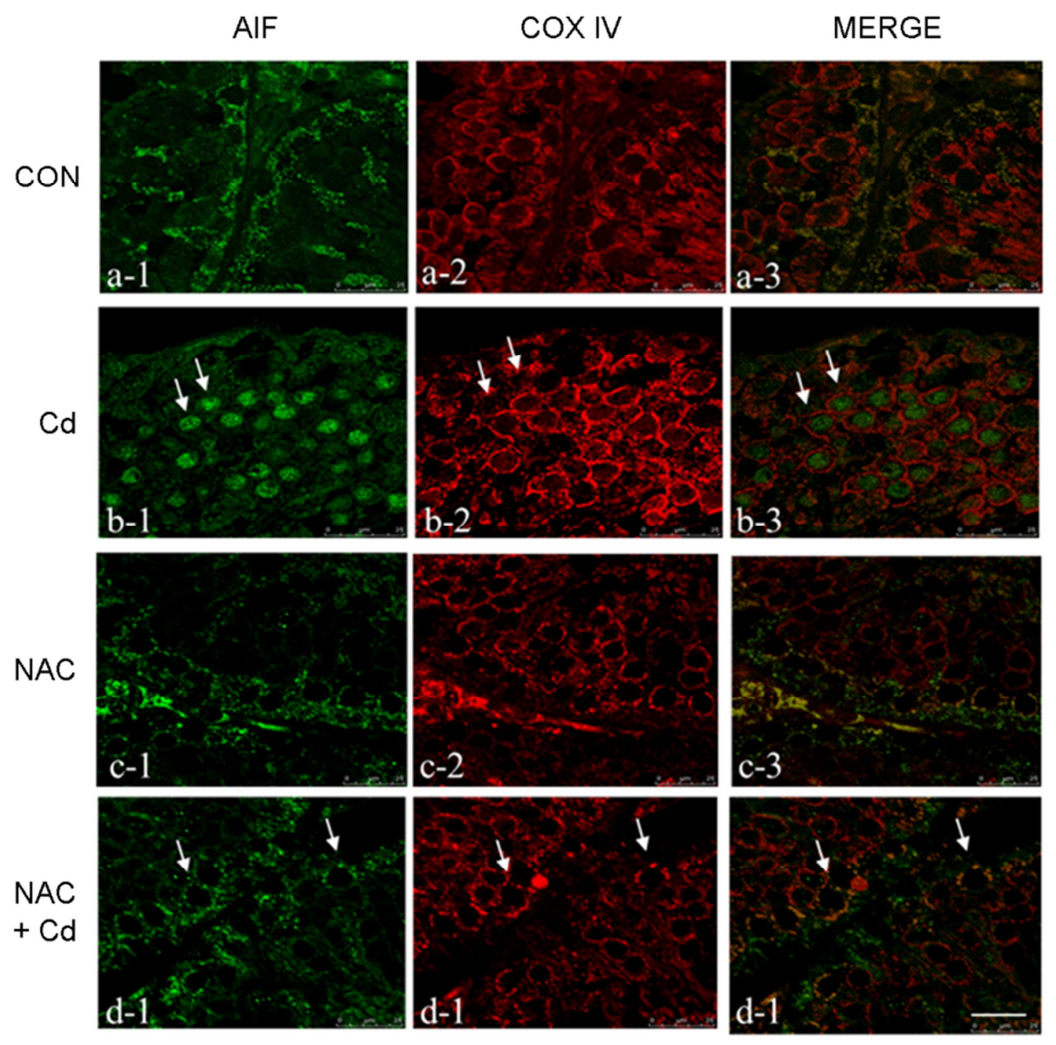

Fig. 5. Translocation of AIF by NAC in Cdinduced rat testicular cells by immunofluorescence assay. Rats were treated with $\mathrm{Cd}$ in the presence or absence of NAC, and testes tissues were fixed and labeled for specific antibodies against AIF (green fluorescence) and COX IV (red fluorescence), which are used for an indicator of mitochondria localization. (a) Control (saline); (b) Cd-only $(0.2 \mathrm{mg} / 100 \mathrm{~g}$ BW) 0.2 ; (c) NAC only; (d) Cd (0.2 mg/100 g BW) + NAC. NAC was administered at $150 \mathrm{mg}$ $/ 100 \mathrm{~g} \mathrm{BW} 24 \mathrm{~h}$ prior to $\mathrm{Cd}$ treatment and further administered three times at $50 \mathrm{mg} / 100 \mathrm{~g}$ $\mathrm{BW}$ at $24 \mathrm{~h}, 16 \mathrm{~h}$, and $8 \mathrm{~h}$ each prior to sacrifice. The arrow indicates the expression of each designated protein. The experiment was repeated three times with similar results. Representative photographs are shown here. The scale bar represents $20 \mu \mathrm{m}$. suggest that Cd-induced ROS production is directly involved in rat testicular apoptosis since the removal of ROS by the administration of AA inhibited apoptosis. These results indicated that the ROS-induced apoptosis signal is transduced through the activation of PPAR-1 and depolarization of the mitochondrial membrane followed by the translocation of AIF from the mitochondria to the nucleus (Shih et al., 2004).

The results showed that the supplementation of NAC in Cd-treated rats decreased DNA fragmentation and the formation of DNA strand breaks when a TUNEL assay was employed. The administration of NAC to Cd-treated rats prevented the translocation of AIF from the mitochondria to the nucleus. These data indicate that $\mathrm{Cd}$-induced ROS is responsible for rat testicular apoptosis and the mechanism of Cd-induced testicular apoptosis mediates the release of AIF in a caspase-independent manner (Cregan et al., 2004).

\section{ACKNOWLEDGEMENT}

None.

\section{CONFLICT OF INTEREST}

The authors have no conflict of interest to declare.

\section{REFERENCES}

Acharya UR, Mishra M, Patro J, Panda MK. Effect of vitamin C and $\mathrm{E}$ on spermatogenesis in mice exposed to cadmium. Reprod Toxicol. 2008. 25: 84-88.

Aldini G, Altomare A, Baron G, Vistoli G, Carini M, Borsani L, Sergio F. N-acetylcysteine as an antioxidant and disulphide breaking agent: the reason why. Free Radic Res. 2018. 52: 751-762.

Ates B, Abraham L, Ercal, N. Antioxidant and free radical scavenging properties of $\mathrm{N}$-acetylcysteine amide (NACA) and comparison with N-acetylcystein (NAC). Free Radic Res. 2008. 42: 372-377.

Cox B, Emili A. Tissue subcellular fractionation and protein extraction for use in mass-spectrometry-based proteomics. Nat Protoc. 2006. 1: 1872-1878.

Cregan SP, Dawson VL, Slack RS. Role of AIF in caspasedependent and caspase-independent cell death. Oncogene. 
2004. 23: $2785-2796$

Dhandra S, Kaur S, Sandhir R. Preventive effect of N-acetyl-Lcystein on oxidative stress and cognitive impairment in hepatic encephalopathy following bile duct ligation. Free Radic Biol Med. 2013. 56: 204-215.

Gomes C, Oh SD, Kim JW, Chun SY, Lee K, Kwon HB, Soh J. Expression of the putative sterol binding protein Stard6 gene is male germ cell specific. Biol Reprod. 2005. 72: 651-658.

Gomes C, Soh J. DnaJC18, novel type III DnaJ family protein, is expressed specifically in rat male germ cells. Dev Reprod. 2017. 21: 237-247.

Jahnukainen K, Chrysis D, Hou M, Parvinen M, Eksborg S, Soder O. Increased apoptosis occurring during the first wave of spermatogenesis is stage-specific and primarily affects midpachytene spermatocytes in the rat testis. Biol Reprod. 2004. 70: 290-296.

Ji YL, Wang H, Zhao XF, Wang Q, Zhang C, Zhang Y, Zhao M, Chen YH, Meng XH, Xu DX. Crosstalk between endoplasmic reticulum stress and mitochondrial pathway mediates cadmiuminduced germ cell apoptosis in testes. Toxicol Sci. 2011. 124: 446-459.

Kaplan M, Atakan IH, Aydogdu N, Aktoz T, Ozpuyan F, Seren G, Tokuc, Inci O. Influence of $\mathrm{N}$-acetylcysteine on renal toxicity of cadmium in rats. Pediatr Nephrol. 2008. 23: 233-241.

Khojastehfar A, Aghaei M, Gharagozloo M, Panjehpour M. Cadmium induces reactive oxygen species-dependent apoptosis in MCF-7 human breast cancer cell line. Toxicol Mech Methods. 2015. 25: 48-55.

Kim J, Soh J. Cadmium-induced apoptosis is mediated by the translocation of AIF to the nucleus in rat testes. Toxicol Letters. 2009. 188: 45-51.

Kondoh M, Araragi S, Sato K, Higashimoto M, Takiguchi M, Sato M. Cadmium induces apoptosis partly via caspase-9 activation in HL-60 cells. Toxicology. 2002. 170: 111-117.

Krantic S, Mechawar N, Reix S, Quirion R. Apoptosis-inducing factor: a matter of neuron life and death. Prog Neurobiol. 2007. 81: 179-196.

Lemarie A, Lagadic-Gossmann D, Morzadec C, Allain N, Fardel O, Vernhet L. Cadmium induces caspase-independent apoptosis in liver Hep3B cells: role for calcium in signaling oxidative stress-related impairment of mitochondria and relocation of endonuclease $\mathrm{G}$ and apoptosis-inducing factor. Free Radic Biol Med. 2004. 36: 1517-1531.

Li M, Kondo T, Zhao QL. Li FJ, Tanabe K, Arai Y, Zhou ZC, Kasuya M. Apoptosis induced by cadmium in human lymph- oma U937 cells through $\mathrm{Ca}^{+}$caplain and caspase-mitochodriadependent pathway. J Biol Chem. 2000. 275: 39702-39709.

Li R, Luo X, Li L, Peng Q, Yang Y, Zhao L, Ma M, Hou Z. The protective effects of melatonin against oxidative stress and inflammation induced by acute cadmium exposure in mice testis. Biol Trace Elem Res. 2016. 170: 152-164.

Li Y, Wu J, Zhou W, Gao E. Association between environmental exposure to cadmium and human semen quality. 2016. 26: 175 $-186$.

Lemarie A, Lagadic-Gossmann D, Morzadec C, Allain N, Fardel O, Vernhet L. Cadmium induces caspase-independent apoptosis in liver Hep3B cells: role for calcium in signaling oxidative stress-related impairment of mitochondria and relocation of endonuclease $\mathrm{G}$ and apoptosis-inducing factor. Free Radic Biol Med. 2004. 36: 1517-1531.

Lopez E, Arce C, Oset-Gasque MJ, Canadas S, Gonzalez MP. Cadmium induces reactive oxygen species generation and lipid peroxidation in cortical neurons in culture. Free Radic Biol Med. 2006. 40: 940-951.

Ognjanovic BI, Markovic SD, Pavlovic SZ, Zikic RV, Stajn AS, Saicic ZS. Effect of chronic cadmium exposure on antioxidant defense system in some tissues of rats: protective effect of selenium. Physiol Res. 2008. 57: 403-411.

Ortiz MS, Forti KM, Suarez Martinez EB, Munoz LG, Husain K, Muniz WH. Effects of antioxidant N-acetylcysteine against paraquat-induced oxidative stress in vital tissues of mice. Int J Sci Basic Appl Res. 2016. 26: 26-46.

Pant N, Kumar G, Upadhyay AD, Gupta YK, Chaturvedi PK. Correlation between lead and cadmium concentration and semen quality. Andrologia. 2015. 47: 887-891.

Sagrista ML, Garcia AE, Africa De Madariaga M, Mora M. Antioxidant and pro-oxidant effect of the thiolic compounds $\mathrm{N}$ acetyl-L-cysteine and glutathione against free radical-induced lipid peroxidation. Free Radic Res. 2002. 36: 329-340.

Sen Gupta R, Kim J, Gomes C, Oh S, Park J, Im WB, Seong JY, Ahn RS, Kwon HB, Soh J. Effect of ascorbic acid supplementation on testicular steroidogenesis and germ cell death in cadmium-treated male rats. Mol Cell Endocrinol. 2004. 30 57-66.

Shih CM, Ko WC, Wu JS, Wei YH, Wang LF, Chang EE, Lo TY, Cheng HH, Chen CT. Mediating of caspase-independent apoptosis by cadmium through the mitochondria-ROS pathway in MRC-5 fibroblasts. J Cell Biochem. 2004. 91: 384-397.

Simon HU, Haj-Yehia A, Levi-Schaffer F. Role of reactive species (ROS) in apoptosis induction. Apotosis. 2000. 5: 415-418. 
Siu PM, Bryner RW, Martyn JK, Alway SE. Apoptotic adaptations from exercise training in skeletal and cardiac muscles. FASEB J. 2004. 18: 1150-1152.

Xu C, Johnson JE, Singh PK, Jones MM, Yan H, Carter CE. In vivo studies of cadmium-induced apoptosis in testicular tissue of rat and its modulation by a chelating agent. Toxicology. 1996. 22: $1-8$.

Zhao X, Cheng Z, Zhu YI, Li S, Zhang L, Luo Y. Effects of paternal cadmium exposure on the sperm quality of male rats and the neurobehavioral system of their offspring. Exp Ther Med. 2015. 10: 2356-2360.

https://doi.org/10.15616/BSL.2019.25.4.417

Cite this article as: Kim JS, Soh J. The Protective Effects of N-Acetyl-L-cysteine on Cadmium-induced Cell Apoptosis in Rat Testis. Biomedical Science Letters. 2019. 25: 417-425. 